\title{
Effects of Urbanization on Landscape Patterns in a Mountainous Area: A Case Study in the Mentougou District, Beijing, China
}

\author{
Yang Yi 1,2, Yuanyuan Zhao 1,2,*, Guodong Ding 1,2, Guanglei Gao ${ }^{1,2}$, Mingchang Shi ${ }^{1,2}$ \\ and Yue $\mathrm{Cao}^{3}$ \\ 1 Key Laboratory of State Forestry Administration on Soil and Water Conservation, \\ Beijing Forestry University, Beijing 100083, China; YangYi2014@bjfu.edu.cn (Y.Y.); \\ dingguodong@bifu.edu.cn (G.D.); gaoguanglei@bjfu.edu.cn (G.G.); shimc@dtgis.com (M.S.) \\ 2 Beijing Engineering Research Center of Soil and Water Conservation, Beijing Forestry University, \\ Beijing 100083, China \\ 3 Yongding Beijing River Management Office, Beijing Municipal Water Affairs Bureau, Beijing 100165, China; \\ 253962862@163.com \\ * Correspondence: yuanyuan0402@126.com; Tel.: +86-10-6233-6614 \\ Academic Editor: Fausto Cavallaro \\ Received: 18 August 2016; Accepted: 10 November 2016; Published: 18 November 2016
}

\begin{abstract}
We explored the process of urbanization in a mountainous area to seek a sustainable urbanization strategy. Previous urbanization research has mainly focused on flat terrain and coastal areas, and urbanization in mountainous areas remains poorly understood. This study integrated geographic information systems, remote sensing, and statistical analysis to quantify landscape patterns dynamics in response to urbanization, with a case study of Mentougou District in Beijing, China from 1985 to 2014 . We found that the total built-up area increased along with the population and economic indicators. The built-up area increased by one-third over the study period, with $73.38 \%$ of the increase from converted cropland and $12.22 \%$ from converted orchard. The urban expansion area was concentrated in the plain sub-region ( $<200 \mathrm{~m}$ elevation, comprising $68.85 \%$ of the expansion area). The landscape patterns varied over this period. For the whole region, the low mountain sub-region and the high mountain sub-region, landscape patterns gradually became more heterogeneous and fragmented, but they showed the opposite trend in the plain sub-region. None of the urbanization indicators (population, economic and built-up land area) were significantly correlated with landscape metrics for the whole region, but they were significantly correlated in the plain sub-region. The impacts of urbanization on landscape patterns were mainly focused on the plain sub-region, and the effects in the low mountain and high mountain sub-regions were weak. Future urban development in mountainous areas should focus on the protection of cropland and local industries as part of a sustainable development strategy for the whole region.
\end{abstract}

Keywords: urbanization; landscape patterns; landscape metrics; mountainous areas; China

\section{Introduction}

Against a background of rapid social and economic development, urbanization has become a significant worldwide phenomenon [1,2]. Global urbanization was less than $20 \%$ in 1990 but exceeded $50 \%$ by 2008 , with no sign that this process will slow down in the near future [3-5]. Landscape patterns, including landscape composition and configuration, affect ecological processes [6]. Landscape patterns are increasingly influenced by urbanization, resulting in a landscape mosaic of natural and managed patches varying in size, shape, and arrangement. For example, urbanization has aggressively consumed cropland, leading to poor land use structure and serious problems threatening ecosystem services and 
human wellbeing [7-9]. Therefore, exploring the effects of urbanization on landscape patterns is of great importance to regional sustainable development.

Studies of landscape patterns under urbanization, particularly on flat terrain and coastal areas, have been conducted under different methods, scales, and disciplines, in combination with data relating to economics, policy, population, ecological systems, and land use [5,10-15]. For example, Aguilera et al. (2011) used landscape metrics to quantify future urban landscape growth in metropolitan areas of Granada [14]. Hepcan et al. (2014) analysed landscape changes and urban sprawl in a Mediterranean coastal region from 1963 to 2005 and found that natural habitats and ecological sustainability had been seriously degraded through urbanization [15]. These studies have laid the foundation for understanding the impacts of urbanization on landscape patterns. They have also shown that defining landscape metrics is important to achieve a better understanding and more accurate characterisation of urban processes and their consequences.

Mountainous areas make up approximately one-quarter of the world's total land area [16]. They are inhabited by one-tenth of the global population, but provide goods and services for more than half of it [17]. Mountainous areas include several kinds of reserved land and complex terrain, in which croplands are consistently invaded during urbanization; agricultural lands and primary productivity have consequently experienced great losses $[18,19]$. Ecological environments and species diversity in mountainous areas may be severely affected [20]. The second session of the World Environment and Development Conference at the World Summit on Sustainable Development in Johannesburg in 2002 stressed the importance of sustainable development of mountainous areas, and countries should be paying it special attention [21]. Therefore, it is critical to discover the effects of urbanization on landscape patterns in mountainous areas experiencing rapid urbanization.

Mentougou District is a mountainous area in the west of Beijing City. It is an ecological barrier of Beijing City; with the rapid urbanization of Beijing, landscape sustainability is a crucial part of regional sustainable development in Mentougou District [22]. However, relevant studies on this issue have rarely been conducted. In this study, we analysed the urbanization dynamics and landscape patterns changes in Mentougou during 1985-2014, and examined the relationship between urbanization and landscape patterns. This study may provide a useful reference for further urban planning in the study area.

\section{Study Area and Methods}

\subsection{Study Area}

Mentougou District is located in northwestern Beijing $\left(115^{\circ} 25^{\prime} \mathrm{E}-116^{\circ} 10^{\prime} \mathrm{E}, 39^{\circ} 48^{\prime} \mathrm{N}-40^{\circ} 10^{\prime} \mathrm{N}\right)$, covering an area $62 \mathrm{~km}$ in length from west to east and $34 \mathrm{~km}$ from north to south, with a total surface area of $1455 \mathrm{~km}^{2}$. Mentougou District is a typical mountainous area, with the plain region (less than $200 \mathrm{~m}$ ) accounting for less than $10 \%$ of the total area [23]. Most of the urbanized area, located in the towns of Longquan and Yongding, lies within the plain (Figure 1).

Statistical data from 2010 showed the level of urbanization in Mentougou District. The GDP of the district was 86.4 billion Yuan. The population of the region was 246,000 households and the agricultural population was 59,000 households. The primary, secondary and tertiary economic sectors accounted for $1.6 \%, 51.4 \%$ and $46.9 \%$ of the GDP, respectively. Revenue from tourism was 10.4 billion Yuan, and the per capita incomes of rural and urban residents were 1267 Yuan and 2531 Yuan, respectively [24]. The district contained a total length of $648 \mathrm{~km}$ of highways, with two state roads, six city roads, 74 rural roads, and more than 300 ditches. The Mentougou District has the highest proportion of mountainous area among the 10 suburban districts in Beijing city. There are 10 towns and 177 villages in Mentougou District. A main valley runs through the whole region, and ditches branching off of it are distributed throughout the region. Overall, the study area has a tree-like form, with economic development occurring along the branches of low elevation. 


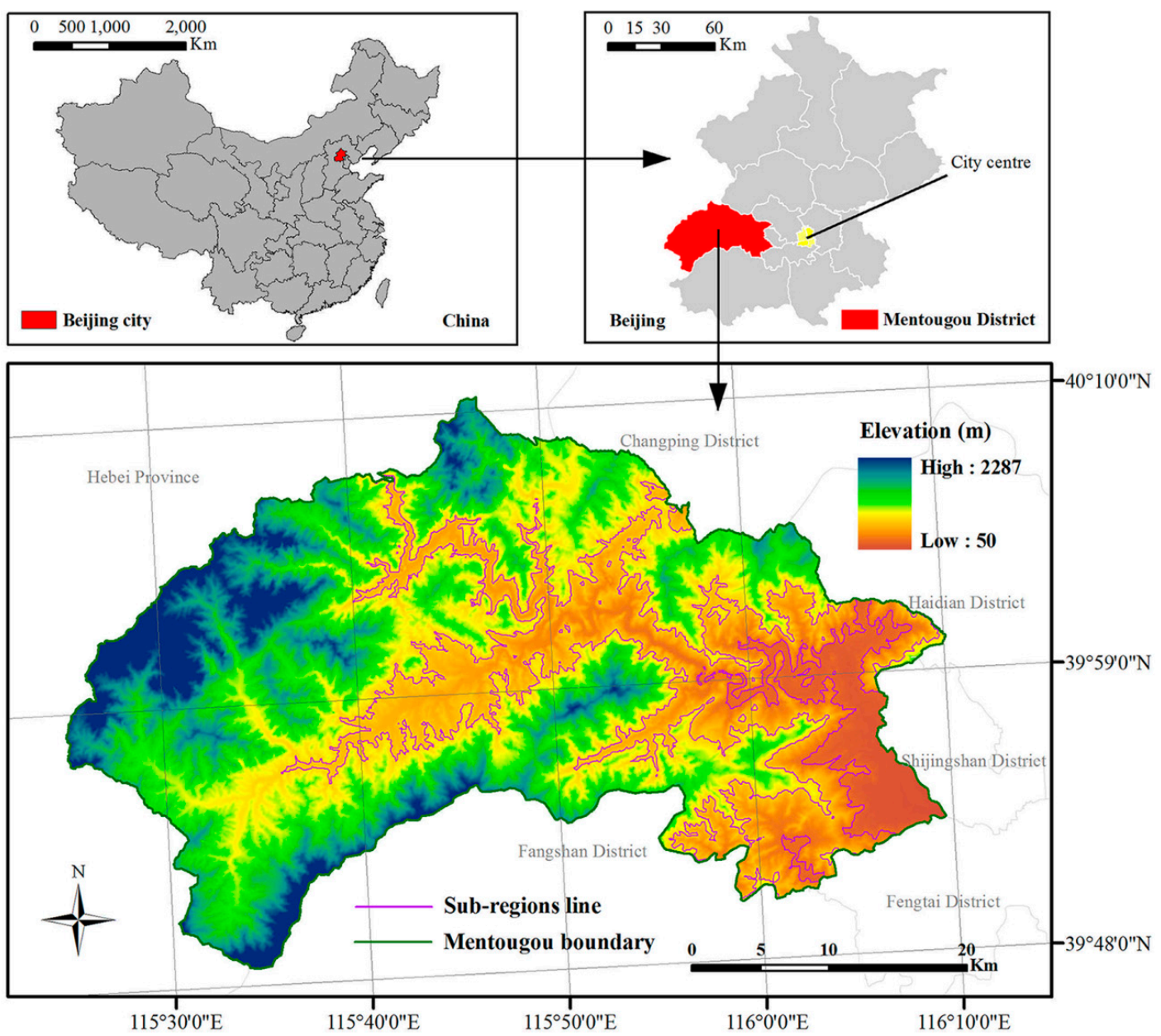

Figure 1. Study area.

\subsection{Data Preprocessing}

We primarily used data from the Landsat Thematic Mapper (TM) (bands 2, 3, 4, 5 and 7) and Operational Land Imager (bands 3, 4, 5, 6 and 7), collecting remote sensing images from seven years spanning a period of 29 years $(1985,1990,1995,2000,2005,2010$ and 2014) [25,26]. The spatial resolution of all data was $30 \times 30 \mathrm{~m}$. The data were preprocessed, including re-projection, mosaic assembly and histogram equalization. Based on the Chinese classification system of land use and the characteristics of land use in the Mentougou District [27,28], we used a maximum likelihood method of classification, which has been widely used in previous research [29]. Land use was classified into nine types: cropland, orchard, forested land, shrubland, grassland, bare land, water bodies, wasteland and built-up land. In the validation procedure, we chose 450 (each land use type had 50 points) representative points distributed throughout the study area using stratified random sampling to examine the accuracy of interpretation with the data from Google Earth and field investigations. Google Earth high-resolution images $(10 \times 10 \mathrm{~m})$ were used to confirm the land use classification prior to 2005, and field investigation was used after 2005. All operations were performed with ERDAS Imagine software, version 9.2.

\subsection{Evaluation of Urbanization}

Based on previous studies [24,30-32], we selected economic indicators (i.e., GDP, per capita income and expenditure of urban residents, per capita income and expenditure of rural residents, primary sector, secondary sector and tertiary sector), permanent resident population and urban land area to evaluate the level of urbanization. Because data regarding the permanent resident population 
before 2005 were scarce, we used the Malthus model to estimate the permanent resident population during 1985-2005 [33].

$$
x_{t}=x_{0} e^{r t}
$$

where $r$ is the net population growth rate, $t$ is the $t$ th year, $x_{t}$ is the population at year $t$, and $x_{0}$ is the initial population.

\subsection{Quantification of Landscape Patterns}

We selected the number of patches (NP), mean patch size (MPS), aggregation index $(A I)$ and patch density $(P D)$ to characterise landscape patterns $[14,34,35]$. We used the following equations to calculate the MPS [36], AI [37] and PD [38]. All calculations were performed with Fragstats 3.3 software.

$$
M P S=\sum_{j=1}^{n} \frac{a_{i j}}{n_{i}}
$$

where $i$ is the $i$ th land use type, $j$ is the $j$ th patch of the $i$ th land use type, $a_{i j}$ is the $j$ th patch area of the $i$ th land use type and $n_{i}$ is the patch number of the $i$ th land use type.

$$
A I=\frac{e_{i, i}}{\max \_e_{i, i}}
$$

where $e_{i, i}$ is the number of adjacent patches with similar land use types.

$$
P D=\frac{n}{A}
$$

where $A$ is the area of the land use type, and $n$ is the number of patches.

$M P S$ is equal to the total area of the landscape divided by the total number of patches of each type, $P D$ refers to the total number of patches per unit area and $A I$ is the weighted average of the agglomeration degree per unit area for each type of patch. A smaller MPS value represents a more fragmented landscape. The degree of spatial heterogeneity increases with increasing $P D$. For $A I$, a high value indicates a landscape with a dominant patch type and a high level of connectivity.

\subsection{Statistical Analysis}

Statistical correlations were calculated between landscape patterns (NP, MPS, PD and $A I$ ) and urbanization indicators. A $p$-value less than 0.05 was considered a significant correlation [39]. Correlations were performed such that a higher absolute value of the correlation coefficient represents a stronger correlation; positive values indicate positive correlations and negative values mean the correlation is negative. All statistical analyses were performed using the PASW Statistics software version 18.0 (SPSS Inc., Chicago, IL, USA, 2016).

Using Chinese terrain classification standards and the natural geography of Mentougou District [40], we classified the study area into three sub-regions: plain sub-region (less than $200 \mathrm{~m}$ above sea level), low mountain sub-region (200-500 m) and high mountain sub-region (higher than $500 \mathrm{~m}$ ). We analysed changes in landscape patterns and their relationships with urbanization indicators in the whole region and sub-regions.

\section{Results}

\subsection{The Urbanization Process in Mentougou District from 1985 to 2014}

Mentougou District has been experiencing rapid and obvious urbanization. From 1985 to 2014, the population increased from 255,000 to 306,000, an increase of one-fifth (Figure 2a). The district's economy also grew substantially over this period, with a 71.16-fold increase in GDP (Figure 2b). The primary, secondary and tertiary economic sectors accounted for $21.33 \%, 54.94 \%$ and $23.73 \%$ 
respectively, of the total GDP in 1985 and $0.90 \%, 50.92 \%$ and $48.18 \%$ in 2014 (Figure 2c). The annual growth rate of per capita income was higher for urban residents $(13.87 \%)$ than for rural residents $(12.27 \%)$. The per capita expenditure of urban residents was 1.68 times that of rural residents in 1985 and 1.95 times as great in 2014 (Figure 2d,e).

We analysed the dynamics of built-up land based on land use data (Table 1), and found that Mentougou District experienced an urban expansion from 1985 to 2014. The area of built-up land increased by $21.11 \mathrm{~km}^{2}$, equal to one-third of the built-up land area in 1985 (Figure 2f). Built-up land was mainly located in the plain and low mountain sub-regions. Cropland, orchard and wasteland were distributed around the built-up land. Most of the forested land was found in the high mountain sub-region (Figure 3).
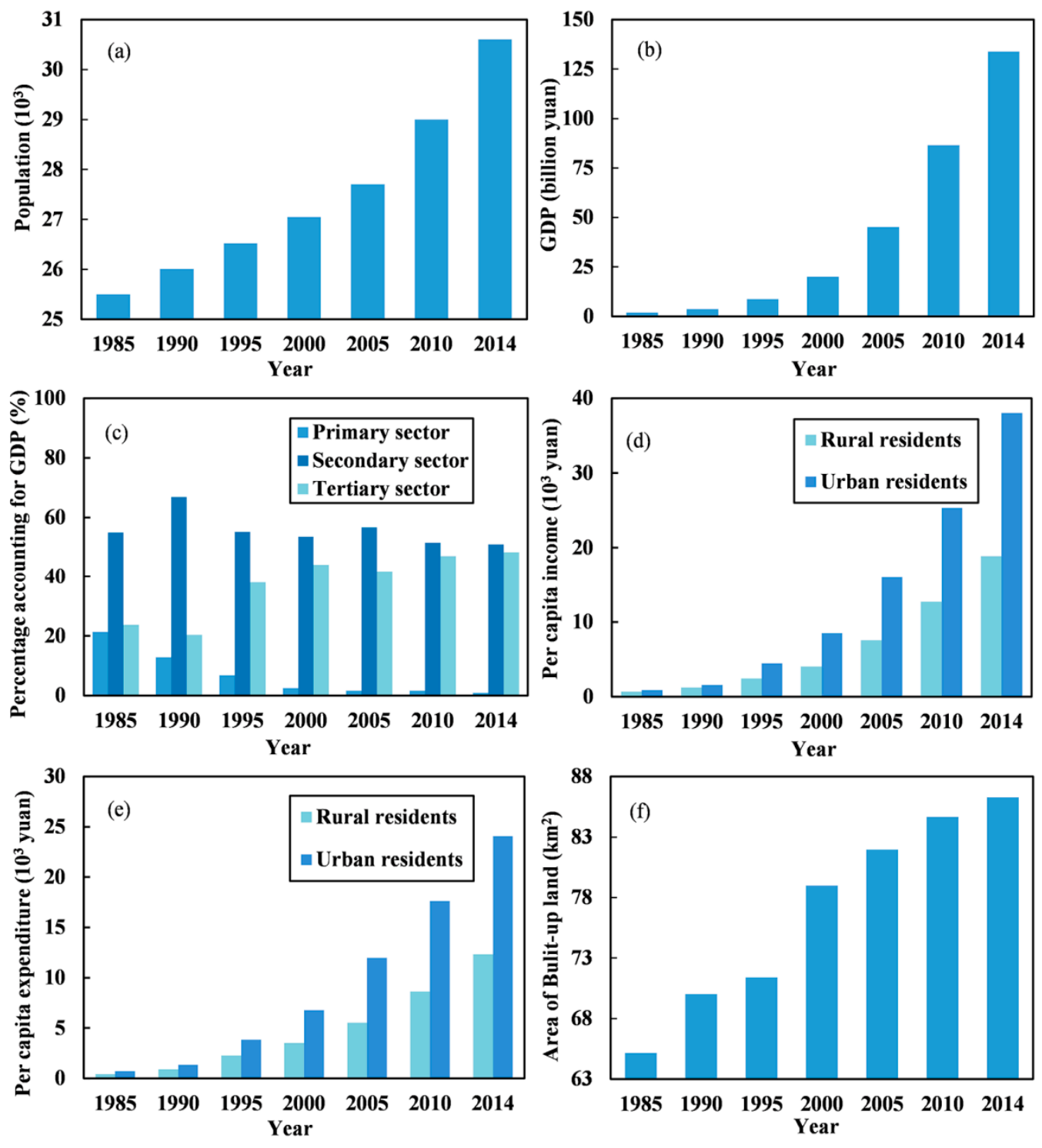

Figure 2. Temporal changes in economic indicators, population and built-up land area. (a) Population; (b) GDP; (c) primary, secondary and tertiary sectors; (d) per capita income of rural and urban residents; (e) per capita expenditure of rural and urban residents; and (f) built-up land area. 
Table 1. Accuracy of data for land use classification.

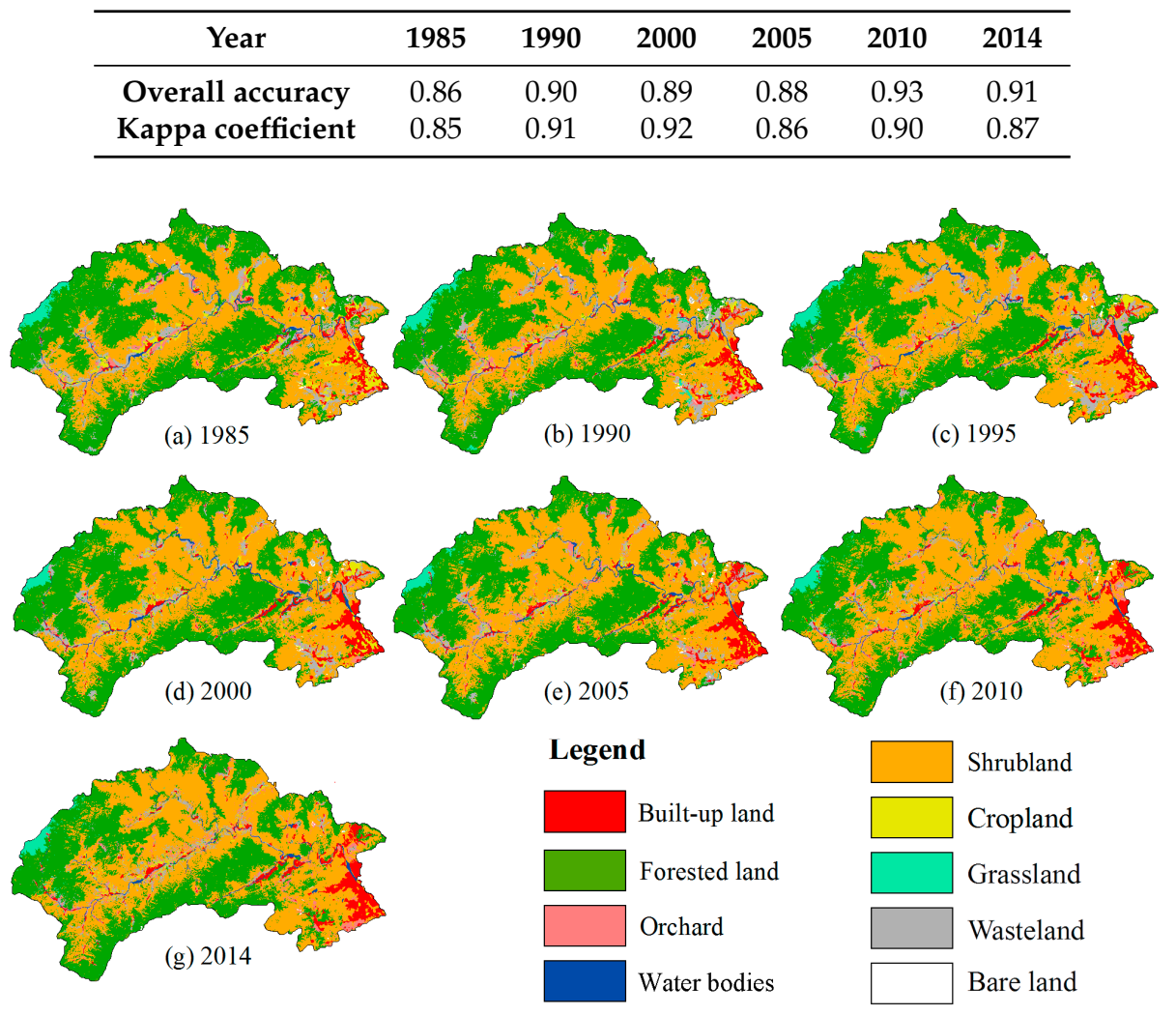

Figure 3. Changes in landscape patterns in the Mentougou District from 1985 to 2014.

\subsection{Changes in Landscape Patterns in Mentougou District from 1985 to 2014}

Across the whole region, approximately $73.38 \%$ of the newly built-up land had previously been cropland and $12.22 \%$ was converted from orchard between 1985 and 2014. This conversion from cropland to built-up land primarily occurred from 1985 to 1990 and from 1995 to 2000, when 3.08 and $5.93 \mathrm{~km}^{2}$ was converted, accounting for $19.32 \%$ and $38.28 \%$ of the total cropland that became built-up land (Table 2). The landscape changes were mainly characterized by an increase in heterogeneity. The NP increased from 6869 in 1985 to 7459 in 2005, then decreased to 7242 in 2014. The MPS decreased from $21.12 \mathrm{~km}^{2}$ in 1985 to $19.45 \mathrm{~km}^{2}$ in 2005 , and then increased to $20.03 \mathrm{~km}^{2}$ in 2014 . The $P D$ increased from 4.73 patches $/ \mathrm{km}^{2}$ in 1985 to 5.14 patches $/ \mathrm{km}^{2}$ in 2005, and then decreased to 4.99 patches $/ \mathrm{km}^{2}$ in 2014. The AI generally decreased between 1985 and 2014 (Figure 4).

Table 2. The area of various land use converted to built-up land over different periods between 1985 and $2014\left(\mathrm{~km}^{2}\right)$.

\begin{tabular}{ccccccccc}
\hline & \multicolumn{7}{c}{ Built-up Land } \\
\cline { 2 - 8 } & $\mathbf{1 9 8 5 - 1 9 9 0}$ & $\mathbf{1 9 9 0 - 1 9 9 5}$ & $\mathbf{1 9 9 5 - 2 0 0 0}$ & $\mathbf{2 0 0 0 - 2 0 0 5}$ & $\mathbf{2 0 0 5 - 2 0 1 0}$ & $\mathbf{2 0 1 0 - 2 0 1 4}$ & $\mathbf{1 9 8 5 - 2 0 1 4}$ \\
\hline Built-up land & 65.15 & 70.02 & 71.39 & 78.98 & 81.96 & 84.67 & 65.15 \\
Orchard & 1.37 & 0.83 & 0.38 & - & - & - & 2.58 \\
Water land & 0.12 & 0.11 & 0.21 & 0.1 & 0.08 & - & 0.62 \\
Cropland & 3.08 & 0.39 & 5.93 & 2.79 & 1.7 & 1.6 & 15.49 \\
Wasteland & 0.3 & 0.04 & 1.07 & 0.08 & 0.93 & - & 2.42 \\
\hline
\end{tabular}



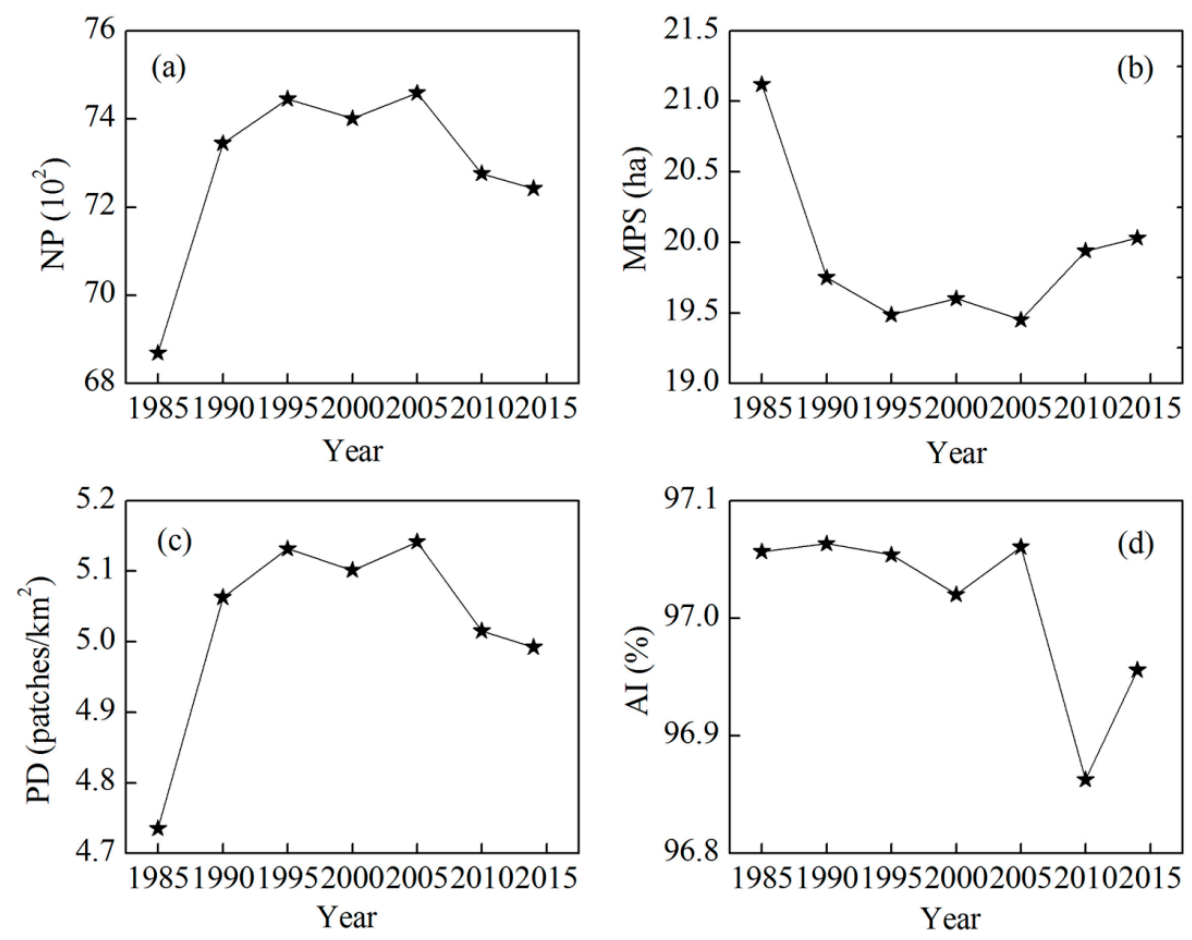

Figure 4. Temporal changes in landscape metrics in Mentougou District. (a) NP; (b) MPS; (c) PD; and (d) $A I$.

Landscape patterns and their changes varied among regions with different elevations. In three sub-regions, built-up land was converted primarily from cropland and was concentrated in the plain sub-region. During the period from 1985 to 2014, the total area of cropland converted to built-up land in the plain sub-region was $10.20 \mathrm{~km}^{2}$, much larger than the areas in the low mountain $\left(4.68 \mathrm{~km}^{2}\right)$ and high mountain sub-regions $\left(1.01 \mathrm{~km}^{2}\right)$. The conversion of orchard to built-up land showed the same pattern. On the other hand, most wasteland converted to built-up land was in the low mountain sub-region, where $1.51 \mathrm{~km}^{2}$ was converted, compared to $0.75 \mathrm{~km}^{2}$ in the plain sub-region and $0.16 \mathrm{~km}^{2}$ in the high mountain sub-region (Table 3).

Table 3. The area of various land use converted to built-up land in different sub-regions of the Mentougou District between 1985 and $2014\left(\mathrm{~km}^{2}\right)$.

\begin{tabular}{cccc}
\hline & \multicolumn{3}{c}{ Built-up Land } \\
\cline { 2 - 4 } & Plain Sub-Region & Low Mountain Sub-Region & High Mountain Sub-Region \\
\hline Built-up land & 34.27 & 20.97 & 9.92 \\
Orchard & 1.9 & 0.68 & - \\
Water land & - & 0.62 & - \\
Cropland & 10.2 & 4.28 & 1.01 \\
Wasteland & 0.75 & 1.51 & 0.16 \\
\hline
\end{tabular}

The temporal changes in landscape patterns varied among the three sub-regions. The NP values in the plain sub-region were lowest, while those in the low mountain sub-region were the highest. Values of MPS in the high mountain sub-region were the largest and were smallest in the low mountain sub-region, while $P D$ were greatest in the low mountain sub-region and smallest in the high mountain sub-region. The largest $A I$ values were found in the plain sub-region and the low mountain sub-region had the smallest values. Generally, NP in the plain sub-region decreased over time, from 395 in 1985 to 372 in 2014. The MPS in the plain sub-region initially decreased from 1985 to 1990, and then increased 
continuously, beginning at $21.74 \mathrm{~km}^{2}$ in 1985 , then $20.35 \mathrm{~km}^{2}$ in 1990 and $23.08 \mathrm{~km}^{2}$ in 2014 . The $P D$ of this sub-region decreased from 4.60 patches $/ \mathrm{km}^{2}$ in 1985 to 4.33 patches $/ \mathrm{km}^{2}$ in 2014 , and the $A I$ increased each year. For the low mountain sub-region, NP increased from 3676 to 4003 between 1985 and 1990, then decreased to 3918 in 1995, and finally, increased to 4012 in 2014. MPS decreased from $9.09 \mathrm{~km}^{2}$ to $8.32 \mathrm{~km}^{2}$ between 1985 and 2014. $P D$ increased from 11.00 to 11.99 patches $/ \mathrm{km}^{2}$ from 1985 to 1990 , decreased to 11.73 patches $/ \mathrm{km}^{2}$ in 1995 , and then increased to $12.01 \mathrm{~km}^{2}$ in 2014 . The $A I$ decreased each year. For the high mountain sub-region, NP increased from 2798 in 1985 to 3100 in 2005, then the decreased to 2858 in 2014. MPS decreased from 36.99 to $36.22 \mathrm{~km}^{2}$ between 1985 and 2014 . The PD increased from 2.70 to 2.76 patches $/ \mathrm{km}^{2}$ from 1985 to 2014 , and the $A I$ decreased each year. Compared with the plain and low mountain sub-regions, the changes measured in the high mountain sub-region were small (Figure 5).
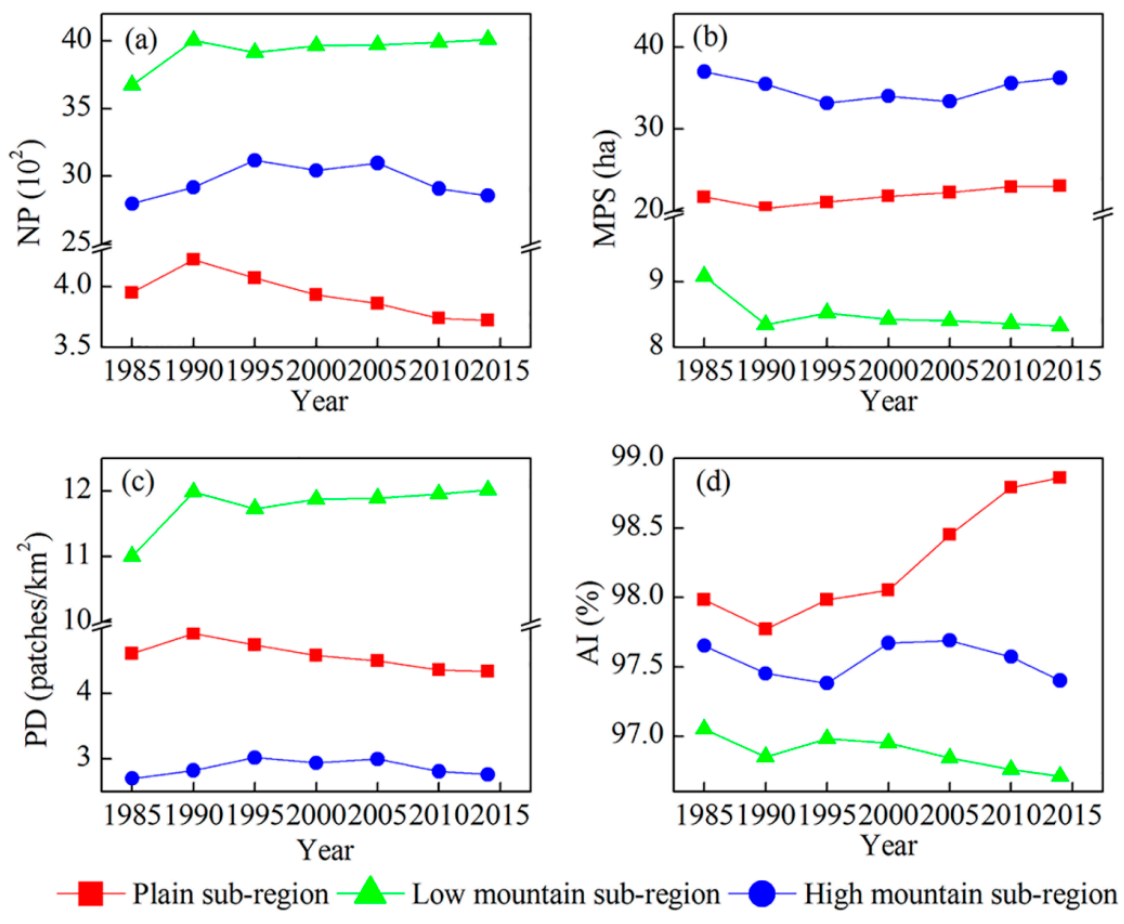

Figure 5. Changes in landscape metrics in three sub-regions with different elevations. (a) NP; (b) MPS; (c) $P D$; and (d) AI.

\subsection{The Relationship between Urbanization Indicators and Landscape Metrics}

There was no significant correlation between urbanization indicators and landscape metrics at the regional scale. But the sign of the correlation changed among sub-regions with different elevations (Table 4). For the plain sub-region, all indicators were significantly negatively correlated with $N P$ and $P D$, and significantly positively correlated with MPS and AI. The $P$ values of all indicators correlated with $A I$ were less than 0.01 , and all other $P$ values were less than 0.05 . All urbanization indicators had relatively high correlation coefficients with $A I$, ranging from 0.88 to 0.97 . For $N P, P D$ and MPS, correlation coefficients with the greatest magnitude were found for the relationship with per capita expenditure of urban residents, with values of $-0.86,-0.86$ and 0.88 , respectively. For the low mountain sub-region, only $A I$ was significantly negatively correlated with urbanization indicators. The $P$ values of all indicators and $A I$ were less than 0.05 . Others had no significant correlation with any indicators. For $A I$, the highest correlation coefficient was with population $(-0.87)$ and the lowest was with the primary economic sector $(-0.82)$. For the high mountain sub-region, there were no significant correlations with any indicators (Table 4). 
Table 4. Correlation coefficients between landscape patterns and urbanization indicators.

\begin{tabular}{|c|c|c|c|c|c|c|c|c|c|c|c|}
\hline & & BL & $\mathbf{P}$ & GDP & FS & SS & TS & PIR & PER & PIU & PEU \\
\hline \multirow{4}{*}{ Region } & $N P$ & 0.43 & 0.19 & 0.04 & 0.06 & 0.06 & 0.03 & 0.09 & 0.15 & 0.11 & 0.16 \\
\hline & MPS & -0.44 & -0.21 & -0.06 & -0.07 & -0.8 & -0.04 & -0.11 & -0.17 & -0.12 & -0.17 \\
\hline & $P D$ & 0.43 & 0.19 & 0.04 & 0.06 & 0.06 & 0.03 & 0.09 & 0.15 & 0.11 & 0.16 \\
\hline & $A I$ & -0.69 & -0.74 & -0.75 & -0.75 & -0.74 & -0.75 & -0.74 & -0.74 & -0.73 & -0.75 \\
\hline \multirow{4}{*}{ Plain sub-region } & $N P$ & $-0.79 *$ & $-0.82 *$ & $-0.83 *$ & $-0.79 *$ & -0.84 * & $-0.83 *$ & $-0.84 *$ & -0.85 * & -0.85 * & $-0.86 *$ \\
\hline & MPS & $0.80 *$ & 0.84 * & $0.85^{*}$ & 0.81 * & 0.86 * & 0.85 * & $0.86^{*}$ & $0.86^{*}$ & $0.87^{*}$ & $0.88^{*}$ \\
\hline & $P D$ & -0.79 * & $-0.82 *$ & $-0.83 *$ & $-0.79 *$ & -0.84 * & $-0.83 *$ & -0.84 * & $-0.85^{*}$ & -0.85 * & $-0.86^{*}$ \\
\hline & $A I$ & $0.88^{* *}$ & $0.94^{* *}$ & $0.95^{* *}$ & $0.93^{* *}$ & $0.95^{* *}$ & $0.94 * *$ & $0.96^{* *}$ & $0.96^{* *}$ & $0.96^{* *}$ & $0.97^{* *}$ \\
\hline \multirow{4}{*}{$\begin{array}{l}\text { Low mountain } \\
\text { sub-region }\end{array}$} & $N P$ & 0.71 & 0.59 & 0.49 & 0.47 & 0.50 & 0.48 & 0.52 & 0.55 & 0.52 & 0.55 \\
\hline & MPS & -0.71 & -0.59 & -0.48 & -0.47 & -0.59 & -0.49 & -0.51 & -0.54 & -0.51 & -0.54 \\
\hline & $P D$ & 0.71 & 0.59 & 0.49 & 0.47 & 0.50 & 0.48 & 0.52 & 0.55 & 0.52 & 0.55 \\
\hline & $A I$ & -0.83 * & $-0.87^{*}$ & $-0.86^{*}$ & $-0.82 *$ & $-0.87^{*}$ & $-0.85^{*}$ & -0.86 * & $-0.86^{*}$ & $-0.86^{*}$ & $-0.86^{*}$ \\
\hline \multirow{4}{*}{$\begin{array}{l}\text { High mountain } \\
\text { sub-region }\end{array}$} & $N P$ & 0.14 & -0.13 & -0.28 & -0.25 & -0.25 & -0.29 & -0.22 & -0.16 & -0.2 & -0.14 \\
\hline & MPS & -0.15 & 0.12 & 0.27 & 0.24 & 0.25 & 0.29 & 0.22 & 0.15 & 0.19 & 0.13 \\
\hline & $P D$ & 0.14 & -0.13 & -0.28 & -0.25 & -0.25 & -0.29 & -0.22 & -0.16 & -0.2 & -0.14 \\
\hline & $A I$ & 0.24 & -0.24 & -0.24 & -0.22 & -0.22 & -0.25 & -0.23 & -0.21 & -0.2 & -0.16 \\
\hline
\end{tabular}

Abbreviations: Built-up land (BL), Population (P), Gross domestic product (GDP), First/primary sector (FS), Secondary sector (SS), Tertiary sector (TS), Per capita income of rural residents (PIR), Per capita expenditure of rural residents (PER), Per capita income of urban residents (PIU) and Per capita expenditure of urban residents (PEU). * $p<0.05 ; * * p<0.01$.

\section{Discussion}

\subsection{Effects of Scale on the Observed Impacts of Urbanization on Landscape Patterns}

Landscape patterns are complex, and different methods have been developed to elucidate, manage, and predict their changes [41]. Wu et al. $(2002,2004)$ concluded that analysis at multiple scales was essential to comprehensively understand an individual study area [42,43]. The changes in landscape patterns during the process of urbanization were analysed at two scales in the present study. The landscape of the whole region became more fragmented between 1985 and 2014, but the impacts of urbanization on this fragmentation were not significant. However, at the sub-region scale, the situation was different. The landscape of the plain sub-region became more uniform, as a large increase in built-up land led to connectivity between built-up areas. As the most common land use type in the plain sub-region, changes in built-up land profoundly influenced the landscape patterns of the plain sub-region overall. For the low mountain sub-region, landscape patterns gradually became more fragmented and heterogeneous. Its MPS was significantly lower than values in the other sub-regions. Small patches of built-up land were produced during urbanization, leading to more patches of cropland, orchard, wasteland and bare land interspersed with the human activity that accompanies built-up land. In the high mountain sub-region, landscape patterns became more fragmented in general, but the changes were much smaller than in other sub-regions. Our results at the sub-regional scale were completely different from those of the regional analysis. Thus, studies conducted at a single scale may not be sufficient to interpret these changes. To fully understand the changes in landscape patterns in the study area, we analysed them at multiple scales.

\subsection{Impacts of Urbanization on Landscape Patterns}

\subsubsection{The Effects of Policy Changes}

The landscape patterns in Mentougou changed significantly during the study period. During this period, the market system began to dominate the region's economy [44]. A large amount of cropland was lost, while built-up land area increased by one-third (Figures 2 and 3). In general, the most fertile land available was used for farming; hence, the loss of cropland leads to significant crop productivity losses, particularly in suburban areas that are experiencing urbanization [45]. The results of our study were consistent with those of previous studies, such as the study that found that the Los Angeles, 
California suburbs of Orange County and San Bernardino County have witnessed a dramatic loss of prime farmland and orange groves to suburban development [46].

The expansion of built-up land in Mentougou was mainly due to conversion of cropland. Influenced by the combination of market liberalization and rapid population growth, built-up land expanded and cropland shrank each year. The "Grain to Green" policy was launched in 1999, prompting further losses of cropland [47]. Future economic development should take into account the unique natural conditions of mountainous areas and their landscape patterns. The government should adapt development and land management policies so that new urban development can be sustainable.

\subsubsection{The Effects of Socio-Economic Growth}

All economic indicators exhibited significant correlations with changes in landscape metrics in the plain sub-region. This showed that economic growth was a strong driving force on the landscape patterns of the plain sub-region. The per capita expenditure of urban residents showed the highest degree of correlation in the plain sub-region, meaning that the per capita expenditure of urban residents was the main indicator of the landscape patterns in the plain sub-region. The only significant correlation between $A I$ and economic indicators occurred in the low mountain sub-region, showing that economic growth has a significant effect on the connectivity of landscape types in this sub-region. On the other hand, economic growth had little correlation with landscape patterns in the high mountain sub-region. Taken together, these results show that maintaining the current urbanization strategy will lead to the area of built-up land in the plain sub-region continuing to expand.

Due to large population movements, the reported household population in Beijing may not reflect the real population. Thus, we chose the permanent resident population as an estimate of population in Mentougou. We also subjected household population to a correlation analysis, and found that it was not significantly correlated with any economic indicators. This may be because after the "one-child policy" in China was implemented in 1983, some residents secretly had more than one child. In order to avoid punishment by the government, they chose to conceal the truth, and did not report the child for official statistics. This led to inaccurate records of household population [48]. Additionally, the mobile population accounted for a large portion of the total population after urbanization. Using the household population may not reflect the real population in the study area. Through statistical analysis, we found that the permanent resident population had significant correlations with landscape patterns in the plain sub-region (Table 4).

\subsection{The Protection of Agricultural Land Should Be Prioritized in the Expansion of Built-up Land during the Process of Urbanization}

During the study period, built-up land replaced a large proportion of the district's cropland due to expansion of the urbanized region, particularly in the plain sub-region (Table 3). The plain sub-region of Mentougou District accounted for less than $10 \%$ of the region's area, but contained more than $60 \%$ of the population [23]. People preferred to build houses in the plain, near the existing residential development [49]. Population pressure in the plain decreased the area of cropland as it was converted to built-up land.

Although the expansion of built-up land took place in areas close to each other during the process of urbanization, they were interspersed with patches of other land types. Cropland was the main land type that disappeared due to urbanization (Figure 3 and Table 2) [50]. The irregular expansion patterns of built-up land led to changes in landscape patterns, especially in the plain sub-region. The results of our study were consistent with those of previous studies [51]. The drastic loss of cropland prompted the government of Mentougou to prioritize the protection of cropland, but it continued to decrease in the plain sub-region. Additionally, some croplands in the low mountain sub-region were also lost during urbanization. Although there was a "Requisition-Compensation Balance" policy to make up for the cropland lost to built-up land expansion, the most fertile cropland was lost and compensation with infertile land caused the productivity of the region to decrease (Figure 3 and Table 3) [52]. At the 
end of 2010, the total area of cropland in China was less than 1.82 billion $\mathrm{km}^{2}$, close to the estimated minimum area of 1.80 billion $\mathrm{km}^{2}$ required to support the country. This decrease prompted the Chinese government to focus on the importance of the protection of existing cropland [53]. Despite this effort, cropland continuously decreased in our study area, which must be brought to the attention of policymakers.

\subsection{Limitations and Future Plans}

Wrbka et al. (2004) and Peterseil et al. (2004) reported problems that could arise from the low spatial resolution of the Landsat TM 30-m resolution images when they were used to describe the details of landscape patterns [54,55]. Due to these problems, the classification of images might need to be repeatedly tested and corrected until the accuracy meets the requirements. The land use in Mentougou was not complicated, and we were able to observe and measure its characteristics over many years of field investigation to overcome this problem with image classification. Nonetheless, improving interpretation accuracy of remote sensing image is always crucial for future work [56]. In addition, the urbanization indicators we used were diverse, and some indicators could not be quantified effectively $[57,58]$ We look forward to future research using more comprehensive indicators, such as culture and infrastructure, to elucidate the dynamic changes caused by urbanization, and to seek an appropriate urbanization strategy for mountainous areas.

\section{Conclusions}

From 1985 to 2014, the plain sub-region in Mentougou District experienced rapid urbanization. The area of built-up land expanded, mainly through the conversion of cropland. The landscape patterns in the whole region, low mountain sub-region and high mountain sub-region became more heterogeneous and fragmented over time, but they became homogenous and connected in the plain. Urbanization were significantly correlated with landscape patterns in the plain and also showed the same sign with landscape connectivity in the low mountain sub-region, but there was little correlation across the whole region and in the high mountain sub-region. Future development of the Mentougou District should strictly limit the loss of cropland during urbanization, and appropriate industries and tourism projects should be introduced. The results of this study provide an important reference for sustainable urban development.

Acknowledgments: This study was financially supported by the Beijing Excellent Talents Training Project (2014000020124G074). We thank Hao Sun and Qingbiao Jiang for their assistance in data collection. The author thanks the anonymous referees for their valuable comments.

Author Contributions: Yang Yi conceived and designed the study with the support of Yuanyuan Zhao and Guanglei Gao. All co-authors drafted and revised the article together. All authors read and approved the final manuscript.

Conflicts of Interest: The authors declare no conflict of interest.

\section{References}

1. Datta, A. New urban utopias of postcolonial India: 'Entrepreneurial urbanization' in Dholera smart city, Gujarat. Dialogues Hum. Geogr. 2015, 5, 3-22. [CrossRef]

2. Glaeser, E.L. A world of cities: The causes and consequences of urbanization in poorer countries. J. Eur. Econ. Assoc. 2014, 12, 1154-1199. [CrossRef]

3. Atack, J.; Bateman, F.; Haines, M.; Margo, R.A. Did Railroads Induce or Follow Economic Growth? Urbanization and Population Growth in the American Midwest, 1850-1860. Soc. Sci. Hist. 2010, 34, 171-197. [CrossRef]

4. Urban Population (\% of Total). Available online: http://data.worldbank.org.cn/indicator/SP.URB.TOTL.IN. ZS?end=2015\&start=1960\&view=chart (accessed on 11 August 2016).

5. Antrop, M. Landscape change and the urbanization process in Europe. Landsc. Urban Plan. 2004, 67, 9-26. [CrossRef] 
6. Fang, J.; Bai, Y.; Wu, J. Towards a better understanding of landscape patterns and ecosystem processes of the Mongolian Plateau. Landsc. Ecol. 2015, 30, 1573-1578. [CrossRef]

7. Turner, W.R.; Nakamura, T.; Dinetti, M. Global Urbanization and the Separation of Humans from Nature. Bioscience 2004, 54, 585-590. [CrossRef]

8. Srinivasan, V.; Seto, K.C.; Emerson, R.; Gorelick, S.M. The impact of urbanization on water vulnerability: A coupled human-environment system approach for Chennai, India. Glob. Environ. Chang. 2013, 23, 229-239. [CrossRef]

9. Esch, T.; Marconcini, M.; Marmanis, D.; Zeidler, J.; Elsayed., S. Dimensioning urbanization—An advanced procedure for characterizing human settlement properties and pattern using spatial network analysis. Appl. Geogr. 2014, 55, 212-228. [CrossRef]

10. Clement, M.T.; Chi, H.; Ho, C. Urbanization and Land-Use Change: A Human Ecology of Deforestation across the United States, 2001-2006. Sociol. Inq. 2015, 85, 628-653. [CrossRef]

11. Ramachandra, T.V.; Aithal, B.H.; Sanna, D.D. Insights to urban dynamics through landscape spatial pattern analysis. Int. J. Appl. Earth Obs. Geoinf. 2012, 18, 329-343.

12. Bhatti, S.S.; Tripathi, N.K.; Nitivattananon, V.; Rana, I.A.; Mozumder, C. A multi-scale modeling approach for simulating urbanization in a metropolitan region. Habitat Int. 2015, 50, 354-365. [CrossRef]

13. Swyngedouw, E.; Moulaert, F.; Rodriguez, A. Neoliberal Urbanization in Europe: Large-Scale Urban Development Projects and the New Urban Policy. Antipode 2002, 34, 542-577. [CrossRef]

14. Aguilera, F.; Valenzuela, L.M.; Botequilha-Leitão, A. Landscape metrics in the analysis of urban land use patterns: A case study in a Spanish metropolitan area. Landsc. Urban Plan. 2011, 99, 226-238. [CrossRef]

15. Hepcan, S.; Hepcan, C.C.; Kilicaslan, C.; Ozkan, M.B.; Kocan, N. Analyzing Landscape Change and Urban Sprawl in a Mediterranean Coastal Landscape: A Case Study from Izmir, Turkey. J. Coast. Res. 2014, 29, 301-310. [CrossRef]

16. Jiang, C.Y. Speech at the annual meeting of the 2002 international mountain area. For. China 2003, 1, 8-9. (In Chinese)

17. Wu, N.; Lu, S.L.; Liu, G.D.; Sun, X.B.; Zhang, Y.G. The origin and goal of "International Mountain year" in 2002. For. Sci. Technol. Manag. 2002, 1, 10-15.

18. Peng, J.; Du, Y.; Liu, Y.; Hu, X. How to assess urban development potential in mountain areas? An approach of ecological carrying capacity in the view of coupled human and natural systems. Ecol. Indic. 2016, 60, 1017-1030. [CrossRef]

19. Xu, D.; Zhang, J.; Rasul, G.; Liu, S.; Xie, F.; Cao, M.; Liu, E. Household Livelihood Strategies and Dependence on Agriculture in the Mountainous Settlements in the Three Gorges Reservoir Area, China. Sustainability 2015, 7, 4850-4869. [CrossRef]

20. Mazzocchi, C.; Sali, G. Sustainability and Competitiveness of Agriculture in Mountain Areas: A Willingness to Pay (WTP) Approach. Sustainability 2016, 8, 343. [CrossRef]

21. United Nations. Report of the World Summit on Sustainable Development. Environ. Politics 2002, 45, 182-221.

22. Bai, Y.; Wang, R.; Jin, J. Water eco-service assessment and compensation in a coal mining region-A case study in the Mentougou district in Beijing. Ecol. Complex. 2011, 8, 144-152. [CrossRef]

23. Zhu, T.F. Land Use/Cover Change and Its Water Resources Effect in North China: A Case Study of Mentougou District, Beijing City. Ph.D. Thesis, China Agricultural University, Beijing, China, 2014. (In Chinese)

24. Beijing Municipal Bureau of Statistics. Beijing Statistical Yearbook. 1985-2014; China Statistic Press: Beijing, China, 1985-2014. (In Chinese)

25. United States Geological Survey. Remote Sensing Images. Available online: https://www.usgs.gov/ (accessed on 11 August 2016).

26. Chinese Academy of Sciences. Geo spatial Data Cloud. Available online: http://www.gscloud.cn/ (accessed on 11 August 2016). (In Chinese)

27. Zhan, C.; Xu, Z.; Ye, A.; Su, H. LUCC and its impact on run-off yield in the Bai River catchment-upstream of the Miyun Reservoir basin. J. Plant Ecol. 2011, 4, 61-66. [CrossRef]

28. Jin, J.; Wang, R.; Li, F.; Huang, J.; Zhou, C.; Zhang, H.; Yang, W. Conjugate ecological restoration approach with a case study in Mentougou district, Beijing. Ecol. Complex. 2011, 8, 161-170. [CrossRef] 
29. Otukei, J.R.; Blaschke, T. Land cover change assessment using decision trees, support vector machines and maximum likelihood classification algorithms. Int. J. Appl. Earth Obs. Geoinf. 2010, 12, S27-S31. [CrossRef]

30. Löffler, R.; Steinicke, E. Counter urbanization and Its Socioeconomic Effects in High Mountain Areas of the Sierra Nevada (California/Nevada). Mt. Res. Dev. 2001, 85, 64-71.

31. Zeng, C.; Cui, J.; Zhang, M.; Liu, B. The comparison of urban and rural built-up land change: A county-level investigation in Wuhan agglomeration. In Proceedings of the 22nd International Conference on Geoinformatics, Kaohsiung, Taiwan, 25-27 June 2014; pp. 1-8.

32. Xu, J.Z. Study on the Data Measurement of GDP in Mentougou District of Beijing City. Master's Thesis, Renmin University of China, Beijing, China, 2008. (In Chinese)

33. Wood, J.W. A theory of preindustrial population dynamics. Demogr. Econ. Well-Being Malthusian Syst. Curr. Anthropol. 1998, 39, 99-135.

34. Deng, J.S.; Wang, K.; Hong, Y.; Qi, J.G. Spatio-temporal dynamics and evolution of land use change and landscape pattern in response to rapid urbanization. Landsc. Urban Plan. 2009, 92, 187-198. [CrossRef]

35. Solon, J. Spatial context of urbanization: Landscape pattern and changes between 1950 and 1990 in the Warsaw metropolitan area, Poland. Landsc. Urban Plan. 2009, 93, 250-261. [CrossRef]

36. Zhou, D.; Zhao, S.; Zhu, C. The grain for green project induced land cover change in the loess plateau: A case study with Ansai County, Shanxi Province, China. Ecol. Indic. 2012, 23, 88-94. [CrossRef]

37. Bogaert, J.; Myneni, R.B.; Knyazikhin, Y. A mathematical comment on the formulae for the aggregation index and the shape index. Landsc. Ecol. 2002, 17, 87-90. [CrossRef]

38. Cao, X.; Ding, S. Landscape pattern dynamics of water body in Kaifeng city in the 20th century. J. Geogr. Sci. 2005, 15, 106-114. [CrossRef]

39. Yasuda, S.; Kachi, S.; Kondo, M.; Ueno, S.; Kaneko, H.; Terasaki, H. Significant Correlation between Retinal Venous Tortuosity and Aqueous Vascular Endothelial Growth Factor Concentration in Eyes with Central Retinal Vein Occlusion. PLoS ONE 2015, 10, e0134267. [CrossRef] [PubMed]

40. The Editorial Committee of Chinese Physical Geography of the Chinese Academy of Sciences. Physical Geography of China: Geomorphology; Beijing Sciences Press: Beijing, China, 1980; pp. 1-61. (In Chinese)

41. Henderson, V. The Urbanization Process and Economic Growth: The So-What Question. J. Econ. Growth 2003, 8, 47-71. [CrossRef]

42. Wu, J.; Shen, W.; Sun, W.; Tueller, P.T. Empirical patterns of the effects of changing scale on landscape metrics. Landsc. Ecol. 2002, 17, 761-782. [CrossRef]

43. Wu, J. Effects of changing scale on landscape pattern analysis: Scaling relations. Landsc. Ecol. 2004, 19, 125-138. [CrossRef]

44. Land Management Law of the People's Republic of China. Available online: http:/ /www.china.com.cn/ chinese/law /647616.htm (accessed on 7 August 2015). (In Chinese)

45. Du, J.; Thill, J.C.; Peiser, R.B. Land pricing and its impact on land use efficiency in post-land-reform China: A case study of Beijing. Cities 2015, 50, 68-74. [CrossRef]

46. Historic Land Use Conversion 1984-2010. Available online: http://www.conservation.ca.gov/dlrp/fmmp/ products/Pages/DownloadGISdata.aspx (accessed on 7 October 2015).

47. People's Government of Mentougou District. Beijing City. Overall Planning of Land Use in Mentougou District (2006-2020). Available online: http://www.mlr.gov.cn/zwgk/ghjh/201204/ P020120424372488783064.doc (accessed on 7 August 2015). (In Chinese)

48. Huang, Z.Y.; Tan, Y.C. Problems and Countermeasures of the rural family planning administrative law enforcement. Theory Contemp. 2004, 2, 32-33. (In Chinese)

49. Su, S.; Li, D.; Zhang, Q.; Xiao, R.; Huang, F.; Wu, J. Temporal trend and source apportionment of water pollution in different functional zones of Qiantang River, China. Water Res. 2011, 45, 1781-1795. [CrossRef] [PubMed]

50. Su, S.; Zhang, Q.; Zhang, Z.; Zhi, J.; Wu, J. Rural settlement expansion and paddy soil loss across an ex-urbanizing watershed in eastern coastal China during market transition. Reg. Environ. Chang. 2011, 11, 651-662. [CrossRef]

51. Yeh, C.T.; Huang, S.L. Investigating spatiotemporal patterns of landscape diversity in response to urbanization. Landsc. Urban Plan. 2009, 93, 151-162. [CrossRef]

52. Guo, F.; Wang, H.; Li, X. Breadless China. China Econ. Wkly. 2013, 25, 24-34. (In Chinese) 
53. People's Government of Mentougou District. Beijing City. Mentougou District New Town Planning (2005-2020). Available online: http://www.bjghw.gov.cn/web/static/articles/catalog_431/article_7477/ 2c94ec281e5d799d011e5d7a75b100c1.doc (accessed on 7 August 2015). (In Chinese)

54. Wrbka, T.; Erb, K.H.; Schulz, N.B.; Peterseil, J.; Hahn, C.; Haberl, H. Linking pattern and process in cultural landscapes: An empirical study based on spatially explicit indicators. Land Use Policy 2004, 21, 289-306. [CrossRef]

55. Peterseil, J.; Wrbka, T.; Plutzar, C.; Schmitzberger, I.; Kiss, A.; Szerencsits, E.; Reiter, K.; Schneider, W.; Suppan, F.; Beissmann, H. Evaluating the ecological sustainability of austrian agricultural landscapes-The sinus approach. Land Use Policy 2004, 21, 307-320. [CrossRef]

56. Maclellan, E.; Soden, R. Harmonizing and combining existing land cover/land use datasets for cropland area monitoring at the African continental scale. Remote Sens. 2012, 5, $19-41$.

57. Liu, Y.; Huang, X.; Yang, H.; Zhong, T. Environmental effects of land-use/cover change caused by urbanization and policies in southwest China Karst area-A case study of Guiyang. Habitat Int. 2014, 44, 339-348. [CrossRef]

58. Long, H.; Liu, Y.; Hou, X.; Li, T.; Li, Y. Effects of land use transitions due to rapid urbanization on ecosystem services: Implications for urban planning in the new developing area of China. Habitat Int. 2014, 44, 536-544. [CrossRef]

(C) 2016 by the authors; licensee MDPI, Basel, Switzerland. This article is an open access article distributed under the terms and conditions of the Creative Commons Attribution (CC-BY) license (http:/ / creativecommons.org/licenses/by/4.0/). 